\title{
23. LATE NEOGENE CALCAREOUS NANNOFOSSIL BIOSTRATIGRAPHY AND PALEOCEANOGRAPHY OF ODP HOLE 677A, PANAMA BASIN ${ }^{1}$
}

\author{
Simon D. Houghton ${ }^{2}$
}

\begin{abstract}
The calcareous nannofossil assemblages recovered from Site 677A range in age from latest Miocene (NN11) to latest Pleistocene. The consistently high sediment-accumulation rate (mean of $48 \mathrm{~m} / \mathrm{m}$.y.) coupled with little dissolution of carbonate has ensured that generally rich, well-preserved coccolith assemblages occur at this site. Exceptions are the Pliocene/Pleistocene boundary sediments, which show evidence of dissolution, and upper Miocene basement sediments, which show evidence of diagenetic overgrowths.

The apparent paradox of the occurrence of large numbers of the cool-water species Coccolithus pelagicus together with subtropical and tropical nannofossil species is thought to represent increased seasonality in the degree of upwelling in the Panama Basin. Seasonal upwelling was particularly intense during the late Miocene, when common $C$. pelagicus occurred with Thalassionema diatoms. Populations of $C$. pelagicus probably bloomed during a winter period of upwelling that was associated with a shallow thermocline and depressed surface-water temperatures.
\end{abstract}

\section{INTRODUCTION}

Five days were spent during Leg 111 of the Ocean Drilling Program (ODP) coring the sedimentary sections at Sites 677 and 678. Site $677\left(1^{\circ} 12.14^{\prime} \mathrm{N}, 83^{\circ} 44.22^{\prime} \mathrm{W}\right)$ is $2750 \mathrm{~m}$ southsouthwest of Hole 504B, in a water depth of $3461 \mathrm{~m}$ (Fig. 1). Two holes were cored at Site 677: Hole 677A penetrated $309.4 \mathrm{~m}$ of sediment consisting mainly of siliceous nannofossil ooze and chalk, with some limestone and chert in the lower section, and Hole $677 \mathrm{~B}, 10 \mathrm{~m}$ north of Hole $677 \mathrm{~A}$, was cored only to the Pliocene/Pleistocene boundary. Cores 111-677A-1H through 111$677 \mathrm{~A}-15 \mathrm{H}$ were recovered with the advanced hydraulic piston coring (APC) technique. Cores 111-677A-16X through 111-677A-34X were recovered using the extended core barrel (XCB) technique.

Site 677 was chosen specifically for detailed biostratigraphic and paleoceanographic studies, with a location in an area of low local heat flow to minimize dissolution and overgrowth effects. Based on nannofossil biochronological evidence, the oldest sediment recovered from Site 677 has an age between 5.2-5.6 and 6.5 Ma. The sedimentation rate (mean of $48 \mathrm{~m} / \mathrm{m}$.y.) shows little variation down to the oldest datum level of $5.95 \mathrm{Ma}$, the last occurrence of the radiolarian Eucyrtidium sp. cf E. diphanes (Shipboard Scientific Party, 1988). The purpose of this preliminary report is to describe the calcareous nannofossil assemblages and their stratigraphic changes at Site 677. Some comments on late Neogene paleoceanographic controls on the abundance and diversity of selected nannofossil groups are also presented.

\section{PROCEDURES}

Smear slide preparation of unprocessed sediments followed standard procedures: a small piece of sediment was smeared onto a glass slide with a drop of distilled water using a flat toothpick. The slide was dried and a cover-slip mounted using "Eukitt." All slides were examined under a Nikon binocular polarizing microscope at a magnification of $1000 \times-1200 \times$, with an oil-immersive objective lens. The relative frequency of the nannofossil species is designated by the following codes:

$\mathrm{A}=$ abundant $(>10 \%$ of total assemblage $)$

$\mathrm{C}=$ common $(1.0 \%-10 \%$ of total assemblage $)$

\footnotetext{
${ }^{1}$ Becker, K., Sakai, H., et al., 1989. Proc. ODP, Sci. Results, 111: College Station, TX (Ocean Drilling Program).

2 Department of Earth Sciences, The Open University, Milton Keynes, Buckinghamshire, MK7 6AA United Kingdom.
}

$$
\begin{aligned}
& \mathrm{F}=\text { few }(0.1 \%-1.0 \% \text { of total assemblage }) \\
& \mathrm{R}=\text { rare }(<0.1 \% \text { of total assemblage }) .
\end{aligned}
$$

A qualitative description of the preservation of the nannofossil assemblages is designated by the following codes:

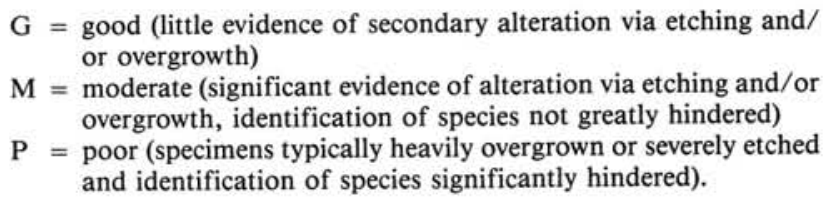

Quantitative nannofossil counts were conducted on the Coccolithus pelagicus group. This technique, described by Backman and Shackleton (1983), is relatively simple to follow and is based on standard smear slide technique. The number of specimens of $C$. pelagicus was counted and expressed as the number per unit area $\left(\mathrm{mm}^{2}\right)$. Approximately 200 nannofossil specimens per $0.03-\mathrm{mm}^{2}$ field of view has been shown to represent a convenient grain density. Forty fields of view, at a magnification of $1000 \times$, were examined for the quantitative counts.

The calcareous nannofossil zonation of Martini (1971) was used to identify the nannofossil zones at Site 677 (Fig. 2 and Tables 1 and 2).

\section{PRESERVATION}

Calcareous nannofossils were recorded in all samples examined. Their preservation varies from good to poor. In uppermost Pleistocene and Pleistocene/Pliocene boundary sediments placoliths show signs of dissolution. Uppermost Pleistocene sediments contain rare Emiliania huxleyi, with most specimens badly corroded. Isolated shields of Calcidiscus leptoporus commonly show signs of etching and breakage. Gephyrocapsa species appear to be the most robust solution-resistant taxa in the Pleistocene assemblages; most of the specimens have their bridges intact, although etching of suture boundaries is apparent. Discoaster and coccolith specimens are well preserved throughout most of the Pliocene section, where high-diversity assemblages are preserved. Coccospheres of Coccolithus pelagicus, Calcidiscus macintyrei, and Reticulofenestra pseudoumbilica occur sporadically in the Pliocene and late Miocene age assemblages. Miocene Discoaster specimens are consistently overgrown, particularly toward the base of the succession, where identification of Discoaster taxa is hindered because of poor preservation. Reworked specimens are a fairly consistent, but minor, component of the nannofossil assemblages and are limited to Discoaster 


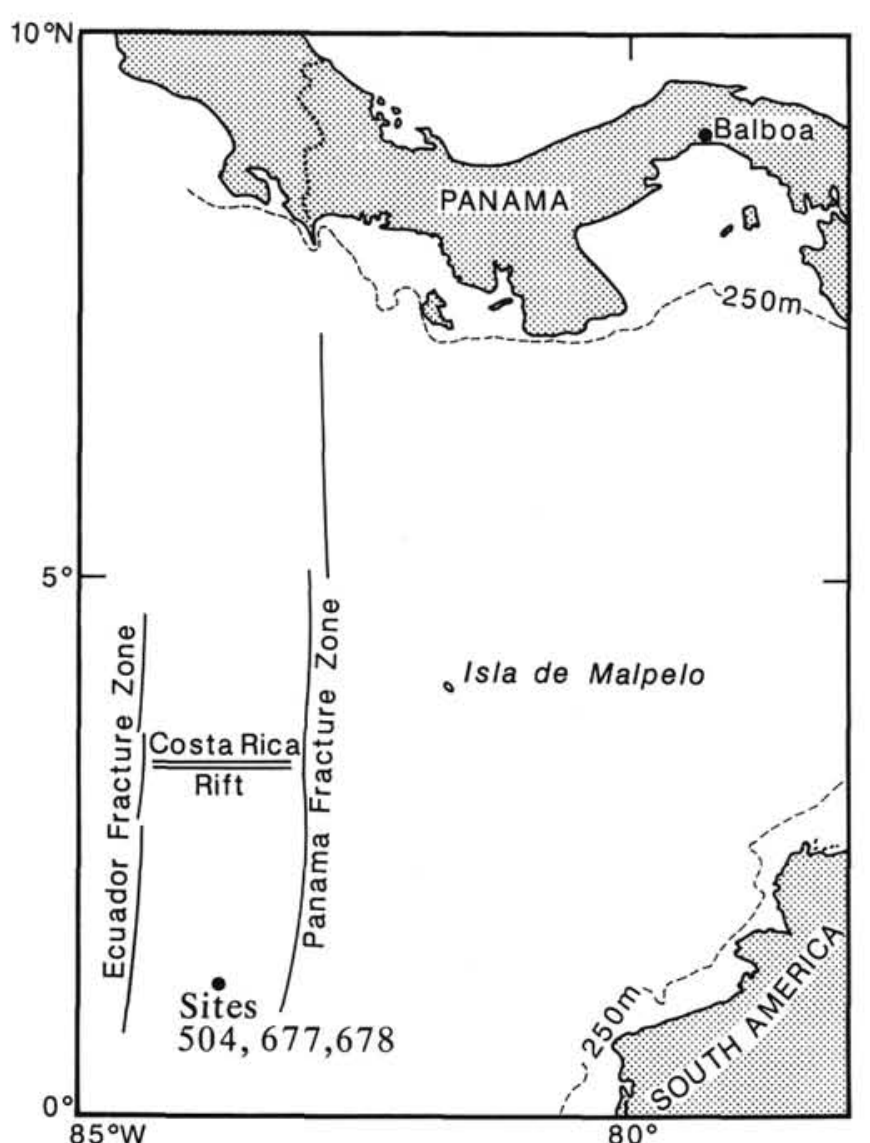

Figure 1. Sites 677,678 , and 504 of ODP Leg 111 in the eastern equatorial Pacific.

Table 1. Species events defining calcareous nannofossil zonal boundaries and their assigned age estimates at Site 677 .

\begin{tabular}{|c|c|c|c|}
\hline \multirow[b]{2}{*}{ Species event ${ }^{a}$} & \multicolumn{2}{|c|}{ Age } & \multirow[b]{2}{*}{ Reference $^{b}$} \\
\hline & Zone & (Ma) & \\
\hline FO Emiliania huxleyi & NN21 & 0.275 & 1 \\
\hline LO Pseudoemiliania lacunosa & $\mathrm{NN} 2 \mathrm{O}$ & 0.475 & 1 \\
\hline LO Helicosphaera sellii & - & 1.37 & 2 \\
\hline LO Calcidiscus leptoporus & - & 1.45 & 2 \\
\hline Pliocene/Pleistocene boundary & & 1.66 & 3 \\
\hline LO Discoaster brouweri & NN19 & 1.89 & 2 \\
\hline LO Discoaster pentaradiatus & NN18 & 2.35 & 2 \\
\hline LO Discoaster surculus & NN17 & 2.46 & 2 \\
\hline LO Discoaster tamalis & - & 2.65 & 2 \\
\hline LO Sphenolithus spp. & & 3.45 & 2 \\
\hline LO Reticulofenestra pseudoumbilica & NN16 & 3.56 & 3 \\
\hline LO Amaurolithus tricorniculatus & NN15 & 3.7 & 4 \\
\hline FO Discoaster asymmetricus & NN14 & 4.1 & 4 \\
\hline LO Amaurolithus primus & & 4.4 & 4 \\
\hline FO Ceratolithus rugosus & $\mathrm{NNl3}$ & 4.6 & 2 \\
\hline LO Ceratolithus acutus & & 4.6 & 2 \\
\hline FO Ceratolithus acutus & & 5.0 & 4 \\
\hline Miocene/Pleistocene boundary & & 5.3 & 4 \\
\hline LO Discoaster quinqueramus & $\mathrm{NN} 12$ & $5.2-5.6$ & 4,5 \\
\hline FO Amaurolithus primus & & 6.5 & 4 \\
\hline
\end{tabular}

Note: All zonal assignments refer to the lower boundary.

${ }^{\mathrm{a}} \mathrm{FO}=$ first occurrence; $\mathrm{LO}=$ last occurrence.

b 1 = Thierstein et al. (1977); 2 = Backman and Shackleton (1983); 3 $=$ Rio et al. (in press); $4=$ Berggren et al. (1985); $5=$ Lohman (1986).

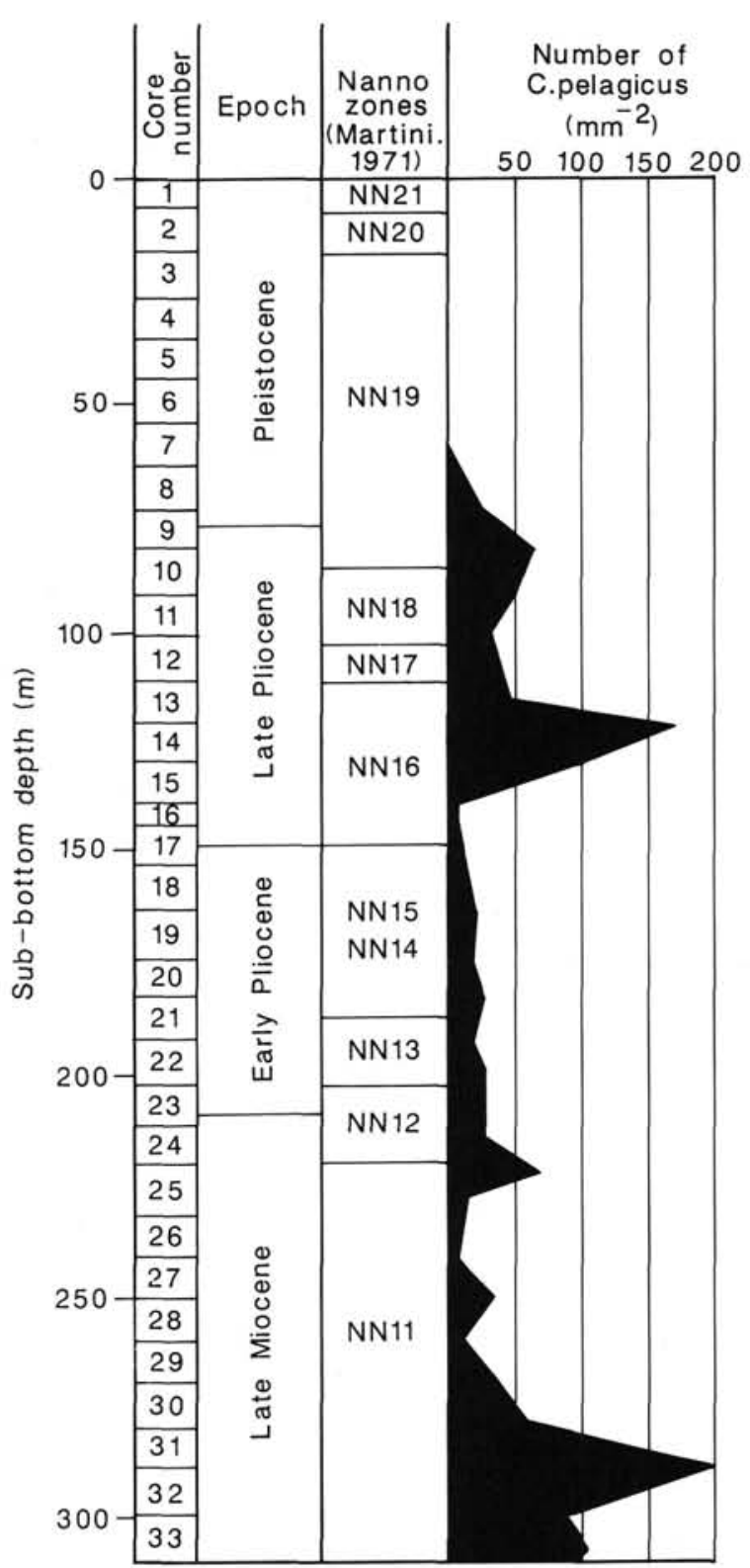

Figure 2. Zonal assignments, epoch boundaries, and the quantitative abundance variation of Coccolithus pelagicus in Hole 677A.

specimens, sphenoliths, and a few robust placolith species (e.g., $R$. pseudoumbilica and C. macintyrei).

\section{HOLE 677A BIOSTRATIGRAPHIC SUMMARY}

\section{Major Boundaries}

The position of the Pliocene/Pleistocene boundary, at 1.66 Ma (Berggren et al., 1985) can be calculated by assuming a constant sediment-accumulation rate in the interval spanning the extinction datums of Coccolithus macintyrei (1.45 Ma) and Discoaster brouweri $(1.89 \mathrm{Ma})$. This boundary is inferred to lie within the middle of Core 111-677A-9H. The early/late Pliocene boundary, based on the extinction of Reticulofenestra pseudoumbilica (3.56 Ma), occurs between Samples 111-677A-17X-3, $70 \mathrm{~cm}$, and 111-677A-17X-CC. The position of the Miocene/Pliocene boundary $(5.3 \mathrm{Ma})$ is calculated to lie within the upper part of Core 111-677A-24X. 
Table 2. Distribution of late Neogene age calcareous nannofossils in Hole 677A.

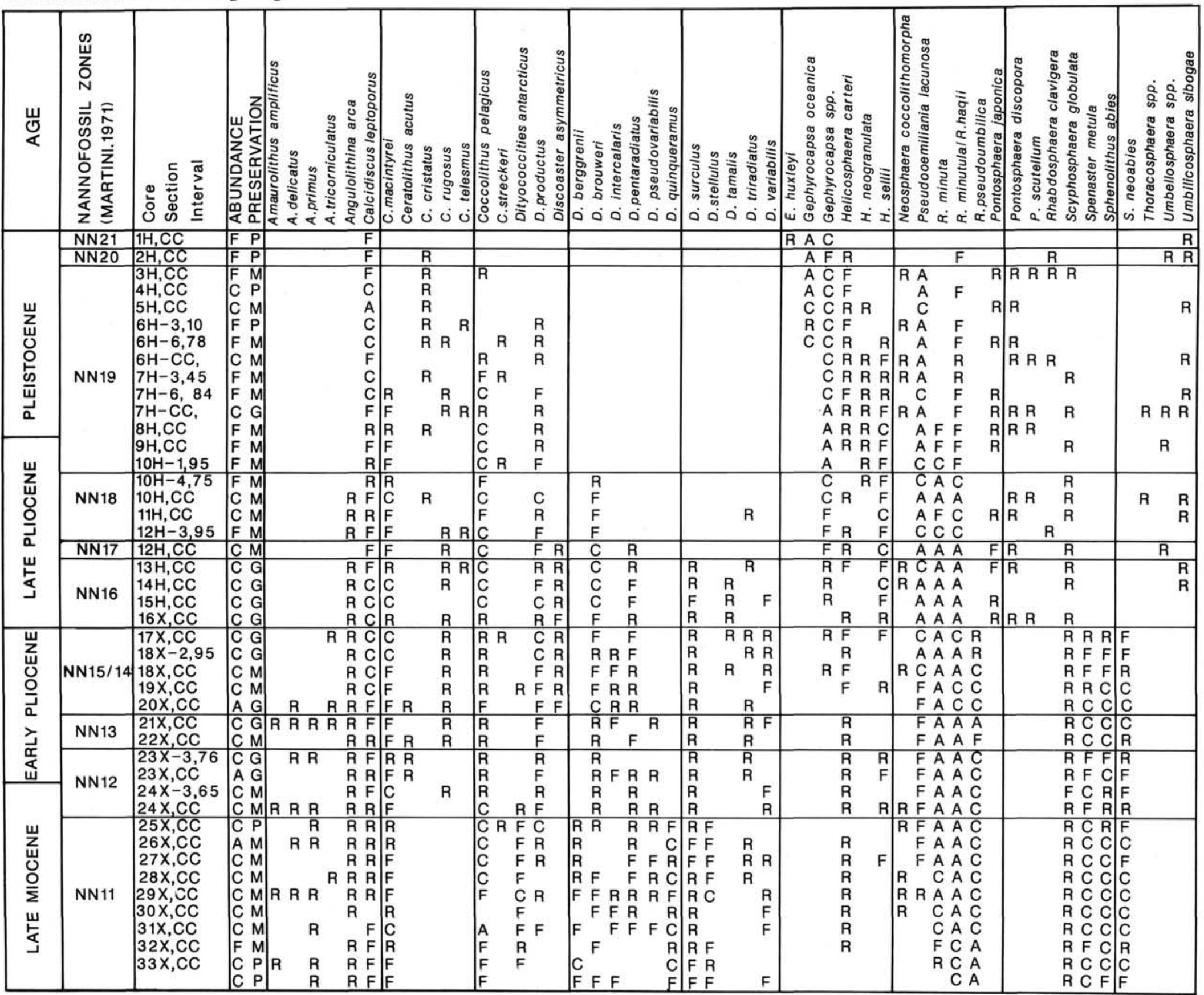




\section{Pleistocene}

The Pleistocene nannofossil assemblages are dominated by Gephyrocapsa spp., Pseudoemiliania lacunosa, and Calcidiscus leptoporus. Lower Pleistocene sediments contain additional species such as Calcidiscus macintyrei, small reticulofenestrids, $\mathrm{He}$ licosphaera neogranulata, Helicosphaera sellii, and Ceratolithus rugosus. Other species commonly noted through the Pleistocene include Helicosphaera carteri, Pontosphaera spp., Syracosphaera spp., Ceratolithus spp., and Umbilicosphaera sibogae.

Scanning electron microscopy (SEM) confirmed the scarce occurrence of Emiliania huxleyi in Sample 111-677A-1H-CC, indicating that the core may be placed within the NN21 Emiliania huxleyi Zone. Although SEM was used to examine the uppermost Pleistocene sediments at Hole 677A, no dominance of $E$. huxleyi was recorded in the assemblages, which contain abundant Gephyrocapsa species. The latest Pleistocene E. huxleyi Zone of Gartner (1977) (base at $0.085 \mathrm{Ma}$ ) was therefore not delineated. The low dominance of $E$. huxleyi in the latest Pleistocene age assemblages is thought to be the result of poor preservation, as the rare specimens of E. huxleyi found in Core 111$677 \mathrm{~A}-1 \mathrm{H}$ are badly corroded, and no intact coccoliths could be found. Gephyrocapsa oceanica occurs without E. huxleyi in Sample 111-677A-2H-CC, which probably indicates that the NN20 Gephyrocapsa oceanica Zone is present.

The last occurrence of $P$. lacunosa in Sample 111-677A-3H-1, $75 \mathrm{~cm}$, indicates the top of the NN19 Pseudoemiliania lacunosa Zone and an age of about $0.475 \mathrm{Ma}$. $\mathrm{H}$. sellii (last occurrence at $1.35 \mathrm{Ma}$ ) has its highest occurrence in Sample 111-677A-6H-6, $78 \mathrm{~cm}$. The extinction of C. macintyrei $(1.45 \mathrm{Ma})$ occurs between Samples 111-677A-7H-6, $84 \mathrm{~cm}$, and 111-677A-7H-3, 45 $\mathrm{cm}$. Between the extinction levels of $C$. macintyrei and $H$. sellii the nannofossil assemblages contain few to common $C$. pelagicus, which continues as a consistent member of the lower Pleistocene assemblages.

\section{Pliocene}

The Pliocene nannofossil assemblages are dominated by reticulofenestrids, Dictyococcities productus, Calcidiscus macintyrei, Discoaster species, and, at certain levels in the upper Pliocene, by Coccolithus pelagicus. Other common species include Calcidiscus leptoporus, Helicosphaera sellii, Helicosphaera carteri, Pontosphaera spp., Scyphosphaera globulata, Angulolithina arca, and ceratoliths.

One of the most important datums in the late Pliocene is the synchronous extinction datum of the Discoaster group (1.89 Ma) represented by the last occurrence of Discoaster brouweri and Discoaster triradiatus (Backman and Shackleton, 1983). The last occurrence of $D$. brouweri is between Samples 111$677 \mathrm{~A}-10 \mathrm{H}-4,75 \mathrm{~cm}$, and $111-677 \mathrm{~A}-10 \mathrm{H}-3,61 \mathrm{~cm}$. The precise location of the D. triradiatus extinction datum at Hole $677 \mathrm{~A}$ cannot be delineated because of the rarity of the species in the upper Pliocene sediments. Backman and Shackleton (1983) showed that the final 0.1-0.2-m.y. range of $D$. brouweri is characterized by a high percentage $(>20 \%)$ of the triradiate form, $D$. triradiatus. The only examined core in which this abundance pattern was not observed was at Site 504, where a minor hiatus was inferred to cover most of this time interval (Backman and Shackleton, 1983). Subsequently, Backman and Pestiaux (1987) refined the age range of the Discoaster triradiatus Acme period, which is estimated to begin at $2.07 \mathrm{Ma}$. The absence of the late Pliocene $D$. triradiatus abundance peak at Site 677 could suggest that the critical time interval (1.89-2.07 Ma) is missing from the cored sedimentary section. However, it is also possible that the $D$. triradiatus Acme period is not a worldwide event and thus cannot be recognized in some oceanic regions, perhaps because of localized paleogeographic and paleoceanographic controls. Localized upwelling events in the Panama Basin are unlikely to have been the main restriction on the abundance of the triradiate form, as the $D$. triradiatus Acme interval is recognized at Sites 662,663 , and 664 of ODP Leg 108, underlying the Benguela Current, a region of strong Pliocene/Pleistocene upwelling and divergence (Ruddiman, Sarnthein, et al., 1988).

The last occurrence of Discoaster pentaradiatus (2.35 Ma) occurs between Samples 111-677A-12H-3, $95 \mathrm{~cm}$, and 111-677A$12 \mathrm{H}-6,25 \mathrm{~cm}$. The highest occurrence of Discoaster surculus occurs in Sample 111-677A-13H-CC, whereas the highest occurrence of both Discoaster tamalis and Discoaster decorus occurs between Samples 111-677A-14H-3, $25 \mathrm{~cm}$, and 111-677A-14HCC. In the zonation of Okada and Bukry (1980) the last occurrence of $D$. tamalis is used to subdivide the Discoaster surculus Zone into a lower Discoaster tamalis Subzone (CN12a) and an upper Discoaster surculus Subzone (CN12b). Backman and Pestiaux (1987) subsequently dated the extinctions of $D$. tamalis $(2.65 \mathrm{Ma})$ and $D$. surculus $(2.46 \mathrm{Ma})$. The first occurrence of $D$. decorus occurs in Sample 111-677A-17X-CC; therefore, the species has a short middle Pliocene range at Hole 667A that is restricted to the uppermost Reticulofenestra pseudoumbilica Zone and the $D$. surculus Zone. A similarly restricted middle Pliocene range for $D$. decorus was also recorded by Bukry (1973) at Deep Sea Drilling Project (DSDP) Site 157 in the Panama Basin, where the species consistently occurs in the D. tamalis Subzone, with only rare occurrences in adjacent subzones.

The next reliable nannofossil datum in the Pliocene is the last occurrence of Reticulofenestra pseudoumbilica (base of NN16), which is dated at $3.56 \mathrm{Ma}$. This highest occurrence of the species is noted in Sample 111-677A-17X-CC. In the $\mathrm{CN}$ zonal scheme of Bukry (1980) the extinctions of $R$. pseudoumbilica and Sphenolithus species are considered synchronous, with both forms delineating the base of the CN12a Subzone. Boudreaux (1974) noted that Sphenolithus abies persisted later than $R$. pseudoumbilica in marginal seas, and he was able to recognize a local Sphenolithus abies Zone. Subsequently, Backman and Shackleton (1983) showed that in tropical environments the extinctions datums of $R$. pseudoumbilica and Sphenolithus species are separated by about $0.1 \mathrm{~m}$.y. These datums can also be distinguished at Site 677 because sphenoliths occur without $R$. pseudoumbilica in Sample 111-677A-17X-3, $70 \mathrm{~cm}$. Sphenaster metula, $S$. abies, and $S$. neoabies also form consistent components of nannofossil assemblages throughout the rest of the lower Pliocene. Small Gephyrocapsa species $(<3.5 \mu \mathrm{m})$ have their first occurrence in the core catcher of Core 111-677A-18X.

Zones NN14 and NN15 were not delineated in Hole 677A because of the scarcity of the marker species Amaurolithus tricorniculatus, which defines the top of the Discoaster asymmetricus Zone. A similar scarcity of $A$. tricorniculatus was noted by Prell, Gardner, et al. (1982) in sediments from DSDP Site 503, which suggests that the species is not a consistent component of lower Pliocene sediments from the Panama Basin. The base of Zone NN14 is placed in Core 111-677A-21X, because the first occurrence of D. asymmetricus is in Sample 111-677A20X-CC. The base of Zone NN13 is marked by the first occurrence of Ceratolithus rugosus $(4.6 \mathrm{Ma})$. This species, together with Ceratolithus acutus, is noted in Sample 111-677A-22X-CC.

Lower Pliocene nannofossil assemblages are characterized by an increase in dominance of $D$. pentaradiatus. These forms are large $(20-30 \mu \mathrm{m})$, show moderate birefringence, have well-defined extinction lines between the arms, and commonly have their bifurcated tips preserved. Upper Pliocene $D$. pentaradiatus specimens are typically smaller, do not show such well-defined extinction lines, and are usually preserved without bifurcated tips.

The first occurrence of $C$. acutus occurs just above the Miocene/Pliocene boundary, in Sample 111-677A-23X-CC; the Mi- 
ocene/Pliocene boundary is therefore assigned to the upper part of Core 111-677A-24X.

\section{Miocene}

The bottom $88 \mathrm{~m}$ of sediment cored from Hole $677 \mathrm{~A}$ is assigned to the late Miocene NN11 (Discoaster quinqueramus Zone). The top of this zone, defined by the last occurrence of the marker species, occurs between Samples 111-677A-25X-1, $124 \mathrm{~cm}$, and the core catcher of Core 111-677A-24X. D. quinqueramus is a common component of the Discoaster assemblages right up to its last occurrence. Other consistently occurring Discoaster species include Discoaster brouweri, Discoaster berggrenii, Discoaster stellulus, Discoaster surculus, Discoaster intercalaris, Discoaster variabilis, large Discoaster pentaradiatus, and Discoaster pseudovariabilis. The late Miocene age nannofossil assemblages are dominated by Reticulofenestra haqii, Reticulofenestra minuta, and Reticulofenestra minutula. Common placolith species include Reticulofenestra pseudoumbilica, Coccolithus pelagicus, and Calcidiscus macintyrei. Sphenoliths are common and include Sphenolithus abies, Sphenolithus neoabies, Sphenaster metula, and rare Sphenolithus verensis. The nonbirefringent ceratoliths Amaurolithus primus (first occurrence $=6.5 \mathrm{Ma}$ ) and Amaurolithus amplificus occur sporadically in the late Miocene age assemblages, although they tend to be more common toward the base of the succession. Scyphosphaera globulata and Angulolithina arca are also consistently recorded. The presence of $A$. primus in the bottommost sediments in Section 111-677A-34X-CC delineates the maximum possible age of the sediments cored at Hole 677A (i.e., about 6.5 Ma).

\section{PALEOCEANOGRAPHY OF SITE 677 AND THE ADJACENT EASTERN EQUATORIAL PACIFIC}

Moore et al. (1973) showed that a latitudinal band of high biological productivity, between $4^{\circ} \mathrm{S}$ and $2^{\circ} \mathrm{N}$ (associated with the Peru Current and equatorial divergence), has existed in the Panama Basin for at least several hundreds of thousands of years. Based on the consistently high accumulation rates at Site $504(50 \mathrm{~m} / \mathrm{m} . \mathrm{y}$.$) and Hole 677 \mathrm{~A}(48 \mathrm{~m} / \mathrm{m} . \mathrm{y}$.), this band must have existed at least during the past $6.0 \mathrm{~m} . \mathrm{y}$. Beiresdorf and Natland (1983) noted that plate tectonic studies have shown that these sites could have migrated only from west to east with respect to the fixed Galapagos melting anomaly. Therefore, Hole $677 \mathrm{~A}\left(1^{\circ} 12.14^{\prime} \mathrm{N}\right)$ should have remained within the zone of high primary productivity near the equator throughout the late Neogene. Although sediment-accumulation rates at Site 677 have remained fairly constant, the relative proportions of the carbonate and siliceous components have varied, probably reflecting variations in the intensity of upwelling in the Panama Basin.

Siliceous productivity in the Panama Basin was high in the late Miocene, for which the particularly high numbers of the Thalassionema group diatoms (Thalassionema and Thalassiothrix) suggest that a major upwelling of the Peru-Chile Current was in process (Sancetta, 1983). Thalassionema nitzschioides is known to be common, or the dominant diatom species, in sediments underlying regions of strong oceanic upwelling and productivity (Sancetta, 1979; Hasle, 1960). At Site 677, a similar high abundance of the Thalassionema group diatoms occurs in the upper Miocene sediments. Particularly high numbers of diatoms occur within Core 111-677A-31X. Associated with this diatom flora is a low-diversity Discoaster assemblage dominated by Discoaster quinqueramus, which forms up to $90 \%$ of the Discoaster assemblage.

The coccolith assemblages associated with the Thalassionema diatoms contain common Coccolithus pelagicus, Reticulofenestra pseudoumbilica, Reticulofenestra haqii, Reticulofenestra minutula, Reticulofenestra minuta, Calcidiscus macintyrei, and Sphenaster metula. The abundance of $C$. pelagicus reaches about 200 specimens $/ \mathrm{mm}^{2}$ (which represents about 5 specimens per field of view at $1000 \times)$ in samples from Core 111-677A$31 \mathrm{X}$, which is about double the next maximum abundance of the form in the upper Miocene sediments (Fig. 2) The inferred association of high numbers of $C$. pelagicus with an upwelling event is consistent with the present ecology of the form. Milliman (1980) recorded blooms of $C$. pelagicus $\left(10^{6}\right.$ cells $\left./ \mathrm{L}\right)$ in surface waters upwelling on shallower parts of Rockall Bank $\left(58^{\circ} \mathrm{N}\right.$, $14^{\circ} \mathrm{W}$ ) in the northeastern Atlantic. The distribution of the species was concentrated in a localized upwelling area, but was absent in waters from the deeper Rockall Trough area. Other reported occurrences of this species in the North Atlantic include the southern Labrador Sea, the Norwegian Sea (Geitzenauer et al., 1977), and the coastal waters off Newfoundland and Shetland (Gaarder, 1954). Records of the species in the Southern Hemisphere are limited mainly to fossil assemblages; however, Hallegraeff (1984) recorded the species in the plankton in the western Tasman Sea $\left(40^{\circ} \mathrm{S}\right)$ near the subtropical convergence.

All these localities reflect the species' ecological preference for dynamic hydrographic regions. The common occurrence of $C$. pelagicus indicates that a significant cool-water element occurred in the photic zone of the late Miocene water column in the Panama Basin (Bukry, 1973). Haq (1980), using an abundance shift of $C$. pelagicus that invaded midlatitudes, also suggested a latest Miocene cold episode, which peaked at about 6 $\mathrm{Ma}$ and lasted until the end of the Miocene. These paleotemperature inferences using abundance variations of $C$. pelagicus are based on the species' present-day distribution in the plankton of the North Atlantic, which is limited to a temperature range of between $14^{\circ}$ and $-1.7^{\circ} \mathrm{C}$ (McIntyre and Bé, 1967; Braarud, 1979). Bukry (1981) noted that the affinity of Coccolithus for cool water had evolved by the Pliocene, but suggested that the application of this same affinity to late Miocene Coccolithus populations must be treated with some caution. Data compiled from DSDP Leg 63 imply that the Coccolithus species Coccolithus miopelagicus and $C$. pelagicus tolerated warm water and that they cannot be employed with confidence as cool-water indicators. Bukry (1981) suggested that the locus of the biogeographic range of Coccolithus has migrated considerably from the middle Miocene to the Holocene, and therefore, it is possible that cool-water upwelling events in the late Miocene were warmer than the present-day higher temperature limit of $C$. pelagicus $\left(14^{\circ} \mathrm{C}\right)$.

The apparent paradox in the occurrence of $C$. pelagicus with tropical and subtropical nannofossil species may indicate an increased seasonal variation in the degree of upwelling and associated surface-water temperatures. Changes in the Holocene hydrography of the Panama Basin are controlled by movements of the Inter-Tropical Convergence Zone (ITCZ), which migrates from $9^{\circ} \mathrm{N}$ latitude during the northern summer to $10^{\circ} \mathrm{S}$ during the northern winter and is accompanied by seasonal variations in surface-water temperature and salinity (Forsbergh, 1969). This dynamic oceanographic regime in the Panama Basin promotes an unusual association of planktonic foraminiferal species for an equatorial region; subtropical and tropical species occur together with Neogloboquadrina pachyderma, Globigerina bulloides, Globigerina quinqueloba, and Globorotalia caverna, which are more diagnostic of subpolar and transitional seas. Thunnel and Reynolds (1984) showed (using sediment traps) that fluxes of the cool-water nonspinose species (e.g., N. pachyderma) occur in February/March during the period of most intense upwelling, associated with a shallow thermocline and depressed surface-water temperatures. Late Miocene $C$. pelagicus populations probably settled to the seafloor during a winter upwelling event. The modern oceanic temperature gradient in the photic zone of the region is $12^{\circ}$ to $27^{\circ} \mathrm{C}$ (Beers and Stewart, 1971). An 


\section{S. D. HOUGHTON}

increased gradient during upwelling events in the late Miocene would have allowed $C$. pelagicus to bloom in the Panama Basin. The tropical and subtropical floras associated with $C$. pelagicus in the sediment (e.g., the blooms of $D$. quinqueramus) probably occurred throughout the remainder of the season. The subtropical coccolith species Umbilicosphaera sibogae is known to bloom during the summer in the Panama Basin (Honjo, 1982).

Above the Miocene/Pliocene boundary, C. pelagicus abundance values are consistently reduced. Lower Pliocene sediments are characterized by diverse, well-preserved nannofossil assemblages and contain higher numbers of ceratoliths and also weakly calcified Discoaster species (e.g., Discoaster brouweri and large Discoaster pentaradiatus). Thalassionema group diatoms parallel the abundance decline of $C$. pelagicus, occurring in greatly reduced numbers in the lower Pliocene sediments. These floral associations suggest a decrease in upwelling and warming occurred in the Panama Basin during the early Pliocene. An early Pliocene warm interval, when upwelling was less intense, was also identified by Bukry (1973) from the Panama Basin record of $C$. pelagicus at DSDP Sites 157 and 158 (Fig. 3). Sancetta (1983) noted a similar trend in siliceous/carbonate sedimentation at Site 504 and suggested a major shift in the pattern of upwellings. This local change in sedimentation patterns in the Panama Basin fits into the global change in opal accumulation at this time. Near the Miocene/Pliocene boundary the accumulation of biogenic opal shifted its locus from the equatorial Pacific to the Southern Ocean (Leinen, 1979; Brewster, 1980). These changes were associated with the intensification of the Polar
Front and led to the Southern Ocean becoming the dominant "sink" for oceanic silica.

The upper Pliocene record from Hole 677A is characterized by an increase in abundance of $C$. pelagicus in the nannofossil assemblages. The dominance of $C$. pelagicus increases abruptly within $D$. surculus Zone sediments and reaches a peak (172 specimens $/ \mathrm{mm}^{2}$ ) in Core 111-677A-13H. This second major peak in abundance of $C$. pelagicus is also associated with biogenic silica, although diatom tests do not reach late Miocene proportions. These sediments also contain rich, well-preserved nannofossil assemblages, including common $D$. brouweri, ceratoliths, Rhabdosphaera, and rare Neosphaera coccolithomorpha. The association of mixed tropical and cool-water floras is thought to indicate seasonal blooms of the two groups and a seasonal upwelling period. Seasonal upwelling was probably most intense in the southern Panama Basin; upper Pliocene abundances of $C$. pelagicus are much greater at Carnegie Ridge (DSDP Site 157; $1^{\circ} 46^{\prime} \mathrm{N}$ ) than at Cocos Ridge (DSDP Site $158 ; 6^{\circ} 37^{\prime} \mathrm{N}$ ) (Bukry, 1973). Optimum growth conditions for $C$. pelagicus may have occurred at Carnegie Ridge as a result of a northward shift of the intense upwelling associated with the Peru Current. Increased upwelling during the late Pliocene may have been associated with the closure of the Isthmus of Panama. Keigwin (1978) suggested that the surface-water connection between the eastern Pacific and the Atlantic was cut off at about $3.1 \mathrm{Ma}$. The suggested closure date of Keigwin correlates well with the sudden increase in the abundance of $C$. pelagicus within the $D$. surculus Zone sediments. The restriction on the flow of water

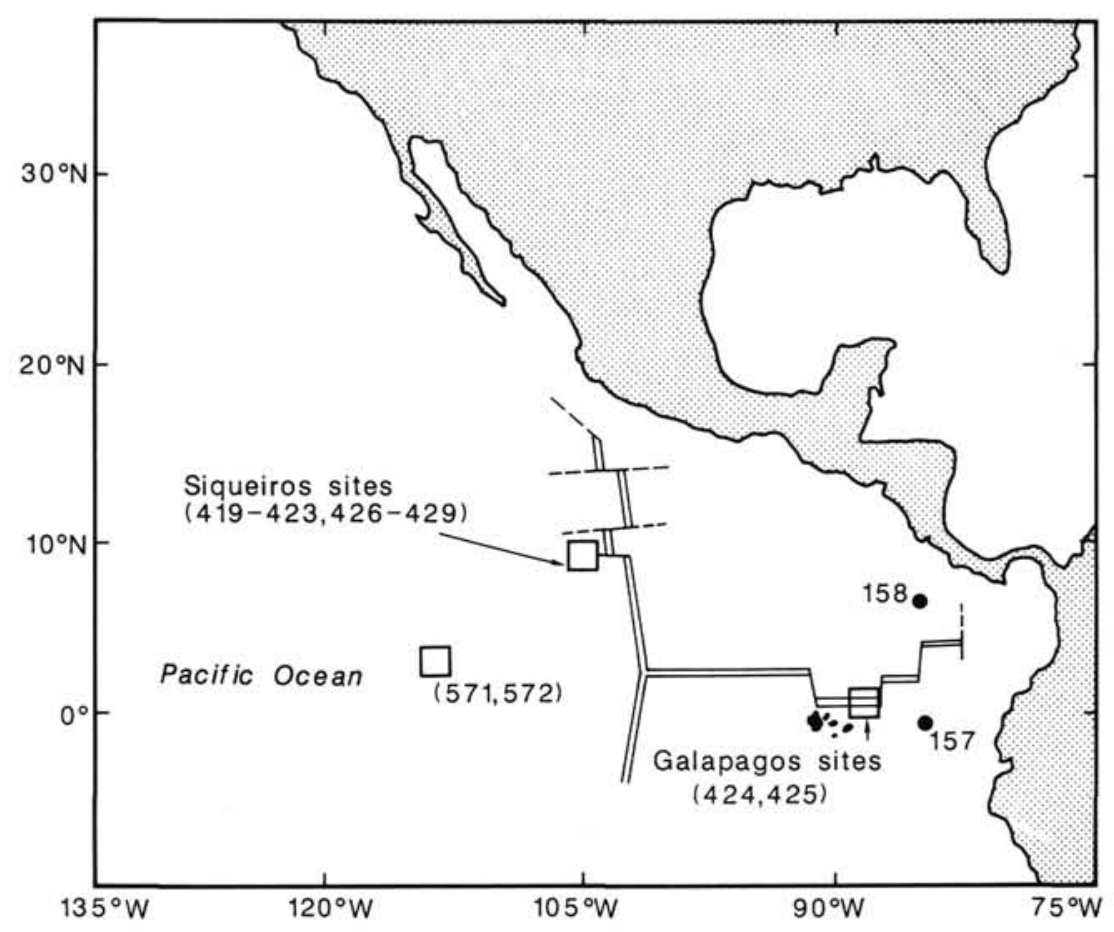

Figure 3. DSDP sites used to define the distribution pattern of Coccolithus pelagicus in the equatorial Pacific. 
through the Central American Seaway may have forced Pacific water to flow westward, with a subsequent increase in upwelling in the Panama Basin.

The absence of Reticulofenestra tanga from the Site 677 sediments is probably a good indication that upwelling only occurred for a short season. $R$. tanga is noted for its abundance in the Miocene of Portugal (Fonseca, 1976) and in the Cenozoic off California (Bukry, 1981), two places that are characterized by an almost permanent upwelling. In DSDP Leg 85 sediments, $R$. tanga was found continuously at Site 572, where permanent upwelling is thought to have occurred since at least $14.5 \mathrm{Ma}$ (Pujos, 1985). At the other Leg 85 sites where upwelling was probably not so prolonged, $R$. tanga was not recorded.

The late Pliocene age assemblages at Site 677 are of lower diversity. Pontosphaera spp. and Scyphosphaera spp. have a sporadic and reduced occurrence and show evidence of dissolution effects. The decline of nannofossil abundances in the uppermost Pliocene/lowermost Pleistocene sediments is associated with a general decline in carbonate in the sediments. Possible causes for the latest Pliocene decrease in nannofossil sedimentation include shoaling of the calcite compensation depth (CCD) and a reduction in calcareous productivity. The CCD may shoal beneath regions of high calcareous productivity, particularly where upwelling introduces cold, corrosive, oxygen-depleted bottom waters into the upper water column (e.g., Berger, 1970, 1973). The $\mathrm{CCD}$ in the Panama Basin as a whole is at about $3400 \mathrm{~m}$, some $1300 \mathrm{~m}$ shallower than in the adjacent equatorial Pacific (Moore et al., 1973). Sancetta (1983) noted that at about $2 \mathrm{Ma}$, a short (0.5-Ma) interval of shoaling of the CCD and decreased productivity occurred at Sites 504 and 505 . This interval is characterized by an increase in clay, and the diatoms are dominated by resistant species. The increased clay content and poor preservation of the diatoms was suggested by Sancetta to represent a period of reduced biological productivity, rather than as the result of increased dissolution of calcite microfossils by corrosive bottom waters. Climatic deterioration during this interval may have reduced nannofossil productivity in the Panama Basin. Planktonic foraminiferal assemblages from Hole 504 sediments provide some evidence for cool-water conditions during the latest Pliocene. The low dominance of the Globorotalia menardii group and common occurrences of $G$. bulloides, together with other cool-water species in the latest Pliocene age cores, are thought to indicate a cool interval (Beiresdorf and Natland, 1983). This may represent the same late Pliocene $(2.0-2.3 \mathrm{Ma})$ glacial maximum identified from ${ }^{18} \mathrm{O}$ contents of benthic foraminifers from the Panama Basin (Keigwin, 1979; Shackleton and Hall, 1983).

C. pelagicus gradually declines in abundance throughout the lower Pleistocene sediments at Hole 677A. Although an isolated specimen of $C$. pelagicus is noted in the core catcher of Core 111-677 A-3H, the species is not recorded again until Sample 111-677A-6H-CC, just above the extinction datum of C. macintyrei $(1.45 \mathrm{Ma})$. The decrease in abundance and disappearance of $C$. pelagicus from the nannofossil assemblages in the eastern equatorial Pacific is time-transgressive. Bukry (1980) noted that C. pelagicus disappeared at the northern Siqueiros sites (approximately $10^{\circ} \mathrm{N}$ ) earlier than at the equatorial Galapagos sites (DSDP Leg 54). C. pelagicus was recorded from the Ceratolithus cristatus Zone (= Gephyrocapsa oceanica Zone in the NN zonal scheme; 0.475-0.275 Ma) at Hole 424 (Galapagos area). At the northern Siqueiros sites, the disappearance of $C$. pelagicus was recorded by Bukry (1980) mainly within the Emiliania annula Subzone (1.89-1.6 Ma).

Farther west $\left(113^{\circ}\right.$ to $\left.135^{\circ}\right)$ in the central equatorial Pacific, Pujos (1985) found that the youngest occurrence of $C$. pelagicus in DSDP Leg 85 (except for Site 571) sediments is limited to the upper part of the Olduvai, close to the Pliocene/Pleistocene boundary. The uppermost Pleistocene sediments at Site 571 however were found to contain very rare $C$. pelagicus. This site is near the northeastern edge of the high productivity area $\left(4^{\circ} \mathrm{N}\right.$, $\left.114^{\circ} \mathrm{W}\right)$, in a zone where some upwelling occurs. The disappearance of $C$. pelagicus in sediments from Hole $677 \mathrm{~A}$ and other sites in the Panama Basin therefore occurs within the Pleistocene, whereas the species' disappearance from more northern and western sites in the tropical Pacific is recorded in the latest Pliocene age sediments. This distribution pattern of $C$. pelagicus in the sediments suggests that during the early Pleistocene the focus of cool, upwelling water was largely restricted to the Panama Basin, at the eastern end of the equatorial Pacific highproductivity area.

The younger Pleistocene sediments at Hole 677A show a return to a more typical tropical association and contain a rich, wellpreserved nannofossil flora, including numerous Pontosphaera, Helicosphaera, N. coccolithomorpha, and rare Scyphosphaera, Umbellosphaera, Syracosphaera, and Ceratolithus. Latest Pleistocene age sediments contain nannofossil assemblages that show moderate dissolution, as evident from the etching on placolith crystal sutures. Dissolution of Holocene carbonate is known to occur in the Panama Basin; studies of sediment traps (Thunnel and Reynolds, 1984) show that of the initial $110.4 \mathrm{~g} / \mathrm{m}^{2} / \mathrm{yr}$ of carbonate that settles to the seafloor, only $17.6 \mathrm{~g} / \mathrm{m}^{2} / \mathrm{yr}$ is incorporated into the sediment. The dissolution of carbonate is probably reflected in the uppermost Pleistocene sediments by reduced occurrences of E. huxleyi, Pontosphaera, and Scyphosphaera.

\section{CONCLUSIONS}

The 310-m sedimentary section drilled at Hole $677 \mathrm{~A}$, from a site of low local heat flow in the Panama Basin, contains diverse, well-preserved nannofossil assemblages. The sediments range in age from latest Miocene (NN11 Zone) to latest Pleistocene. The association of large numbers of the cool-water species Coccolithus pelagicus and Thalassionema group diatoms together with subtropical and tropical nannofossil assemblages is thought to represent increased seasonality in the degree of upwelling in the Panama Basin. Seasonal fluxes of $C$. pelagicus were highest during the late Miocene, when winter upwelling events, associated with a shallow thermocline and lower surfacewater temperatures, are thought to have been particularly intense.

\section{ACKNOWLEDGMENTS}

Financial support for the participation on ODP Leg 111 was provided by NERC. Dr. D. G. Jenkins, Judith Jenkins, Liz Harper, and an anonymous reviewer are thanked for reading an earlier draft of this manuscript.

\section{REFERENCES}

Backman, J., and Pestiaux, P., 1987. Pliocene Discoaster abundance variations, Deep Sea Drilling Project Site 606: biochronology and paleoenvironmental implications. In Ruddiman, W. F., Kidd, R. B., et. al., Init. Repts. DSDP, 94: Washington (U.S. Govt. Printing Office), 903-910.

Backman, J., and Shackleton, N. J., 1983. Quantitative biochronology of Pliocene and early Pleistocene calcareous nannofossils from the Atlantic, Indian and Pacific oceans. Mar. Micropaleontol., 8:141170.

Beers, J. R., and Stewart, G. L., 1971. Micro-zooplankters in the plankton communities of the upper waters of the eastern tropical Pacific. Deep Sea Res., Part A: 18:861-883.

Beiersdorf, H., and Natland, J. H., 1983. Sedimentary and diagenetic processes in the central Panama Basin since the late Miocene: the lithology and composition of sediments from DSDP Sites 504 and 505. In Cann, J. R., Langseth, M. G., Honnorez, J., Von Herzen, R. P., White, S. M., et al., Init. Repts. DSDP, 69: Washington (U.S. Govt. Printing Office), 445-471.

Berger, W. H., 1970. Biogenous deep-sea sediments, fractionation by deep-sea circulation. Geol. Soc. Am. Bull., 81:1385-1402. 
1973. Cenozoic sedimentation in the eastern tropical Pacific. Geol. Soc. Am. Bull., 84:1941-1954.

Berggren, W. A., Kent, D. V., and Flynn, J. J., 1985. Neogene geochronology and chronostratigraphy. In Snelling, N. J. (Ed.), Geochronology and the Stratigraphic Record: Geol. Soc. Lond. Spec. Publ., 10: 211-260.

Boudreaux, J. E., 1974. Calcareous nannoplankton ranges, Deep Sea Drilling Project, Leg 23. In Whitmarsh, R. B., Weser, O. E., Ross, D. A., et al., Init. Repts. DSDP, 23: Washington (U.S. Govt. Printing Office), 1073-1090.

Braarud, T., 1979. The temperature range of the non-motile stage of Coccolithus pelagicus in the North Atlantic region. Br. Phycol. J., $14: 349-352$.

Brewster, N. A., 1980. Cenozoic biogenic silica sedimentation in the Antarctic Ocean. Geol. Soc. Am. Bull., 91:337-347.

Bukry, D., 1973. Coccolith stratigraphy, eastern equatorial Pacific, Leg 16, Deep Sea Drilling Project. In van Andel, T. H., Heath, G. R., et al., Init. Repts. DSDP, 16: Washington (U.S. Govt. Printing Office), 653-711.

1980. Coccolith stratigraphy, tropical eastern Pacific Ocean, DSDP Leg 54. In Rosendahl, B. R., Hekinian, R., et al., Init. Repts. DSDP, 54: Washington (U.S. Govt. Printing Office), 535545 .

1981. Pacific coast coccolith stratigraphy between Conception and Caba Corrientes, Deep Sea Drilling Project, Leg 63. In Yeats, R. S., Haq, B. U., et al., Init. Repts. DSDP, 63: Washington (U.S. Govt. Printing Office), 445-471.

Fonseca, B., 1976. Coccolithus taganus, nouvelle espece de coccolithophoridé du Miocene de Lisbonne. Biol. Soc. Geol. Portugal, 20:29-32.

Forsbergh, E. D., 1969. On the climatology, oceanography and fisheries of the Panama Bight. Bull. Inter-Am. Trop. Tuna Comm., 14:49385 .

Gaarder, K. R., 1954. Coccolithineae, silicoflagellates, Pterospermatacaea and other forms from the Michael Sars North Atlantic DeepSea Expedition, 1910. Rep. Michael Sars N. Atl. Deep Sea Exped., 12:1-20.

Gartner, S. Jr., 1977. Calcareous nannofossil biostratigraphy and revised zonation of the Pleistocene. Mar. Micropaleontol., 2:1-25.

Gietzenauer, K. R., Roche, M. B., and Mclntyre, A., 1977. Coccolith biogeography from North Atlantic and Pacific surface sediments. In Ramsay, A. (Ed.), Oceanic Micropalaeontology (vol. 2): New York (Academic Press), 973-1008.

Hallegraeff, G. M., 1984. Coccolithophorids (calcareous nannoplankton) from Australian waters. Bot. Mar., 17:229-247.

Haq, B. U., 1980 Biogeographic history of Miocene calcareous nannoplankton and paleoceanography of the Atlantic Ocean. Micropaleontology, 26:414-443.

Hasle, G. R., 1960. Phytoplankton and ciliate species from the tropical Pacific. Skr. Nor. Vidensk. Akad. Math. Nat. Kl., 2:1-50.

Honjo, S., 1982. Seasonality and interaction of biogenic and lithogenic particulate flux at the Panama Basin. Science, 218:883-834.

Keigwin, L. D., 1978. Pliocene closing of the Isthmus of Panama based on biostratigraphic evidence from nearby Pacific and Caribbean sea cores. Geology, 6:630-634.

1979. Late Cenozoic stable isotope stratigraphy and paleoceanography of DSDP sites from the east equatorial and central Pacific Ocean. Earth Planet. Sci. Lett., 45:361-382.

Leinen, M., 1979. Biogenic silica accumulation in the central equatorial and central Pacific Ocean. Earth Planet. Sci. Lett., 45:1059-1193.

Lohman, W. H., 1986. Calcareous nannoplankton biostratigraphy of the southern Coral Sea, Tasman Sea and Southwestern Pacific Ocean. Deep Sea Drilling Project, Leg 90: Neogene and Quaternary. In Kennett, J. P., von der Borch, C. C., et al., Init. Repts. DSDP, 90: Washington (U.S. Govt. Printing Office), 763-77.

Martini, E., 1971. Standard Tertiary and Quaternary calcareous nannoplankton zonation. In Farinacci, A. (Ed.), Proc. Planktonic Conf. II Rome 1970: (Ed. Technoscienze), 2:739-785.

Mclntyre, A., and Bé, A.W.H., 1967. Modern coccolithophoridae of the Atlantic Ocean. 1. Placoliths and crytoliths. Deep Sea Res., Part A, 14:561-597.

Milliman, J. D., 1980. Coccolithophorid production and sedimentation, Rockall Bank. Deep Sea Res., Part A, 27:959-963.

Moore, T. C., Jr., Heath, R. C., and Konsmann, R. O., 1973. Biogenic sediments of the Panama Basin. J. Geol., 81:458-472.
Okada, H., and Bukry, D., 1980. Supplementary modification and introduction of code numbers to the low-latitude coccolith biostratigraphic zonation (Bukry, 1973-1975). Mar. Micropaleontol., 5:321325 .

Prell, W. L., Gardner, J. V., et al., 1982. Init. Repts. DSDP, 68: Washington (U.S. Govt. Printing Office).

Pujos, A., 1985. Cenozoic nannofossils. central equatorial Pacific, Deep Sea Drilling Project Leg 85. In Mayer, L., Theyer, F., Thomas, E., et al., Init. Repts. DSDP, 85: Washington (U.S. Govt. Printing Office), 581-607.

Rio, D., Backman, J., and Raffi, I., in press. Calcareous nannofossil biochronology and the Pliocene/Pleistocene Boundary. In Van Couvering, J. (Ed.), The Pliocene/Pleistocene Boundary: Definition and Worldwide Correlation: Cambridge (Cambridge Univ. Press).

Ruddiman, W. F., Sarnthein, M., et al., 1988. Proc. ODP, Init. Repts., 108: College Station, TX (Ocean Drilling Program).

Sancetta, C. A., 1979. Oceanography of the North Pacific during the last 18,000 years: evidence from fossil diatoms. Mar. Micropaleontol., 4:103-123.

,1983. Biostratigraphic and paleoceanographic events in the eastern equatorial Pacific: results of the Deep Sea Drilling Project Leg 69. In Cann, J. R., Langseth, M. G., Honnorez, J., Von Herzen, R. P., White, S. M., et al., Init. Repts. DSDP, 69: Washington (U.S. Govt. Printing Office), 311-320.

Shackleton, N. J., and Hall, M. A., 1983. Stable isotope record of Hole 504 sediments: high resolution record of the Pleistocene. In Cann, J. R., Langseth, M. G., Honnorez, J., Von Herzen, R. P., White, S. M., et al., Init. Repts. DSDP, 69: Washington (U.S. Govt. Printing Office), 431-442.

Shipboard Scientific Party, 1988. Sites 677 and 678. In Becker, K., Sakai, H., et al., Proc. ODP, Init. Repts., 111: College Station, TX (Ocean Drilling Program), 253-346.

Thierstein, H. R., Geitzenauer, K. R., Molifino, B., and Shackleton, N. J., 1977. Global synchroneity of late Quaternary coccolith datum levels: validation by oxygen isotopes. Geology, 5:400-404.

Thunnel, R. C., and Reynolds, L. A., 1984. Sedimentation of planktonic foraminifera: seasonal changes in species flux in the Panama Basin. Micropaleontology, 30:243-262.

Date of initial receipt: 17 June 1988

Date of acceptance: 19 December 1988

Ms 111B-148

\section{APPENDIX}

Calcareous Nannofossil Taxa Recorded at Site 677

Sphenolithus abies Deflandre, 1954

Ceratolithus acutus Gartner and Bukry, 1974

Amaurolithus amplificus (Bukry and Percival, 1971) Gartner and Bukry, 1975

Dictyococcities antarcticus Haq, 1976

Angulolithina arca Bukry, 1973

Discoaster asymmetricus Gartner, 1969

Discoaster berggrenii Bukry, 1971

Discoaster blackstockae Bukry, 1971

Discoaster brouweri Tan, 1927

Helicosphaera carteri (Wallich, 1887) Kamptner, 1954

Discoaster challengeri Bramlette and Riedel, 1954

Rhabdosphaera clavigera Murray and Blackman, 1898

Neosphaera coccolithomorpha Lecal-Schlauder, 1950

Ceratolithus cristatus Kamptner, 1954

Discoaster decorus (Bukry, 1971) Bukry, 1973

Amaurolithus delicatus Gartner and Bukry, 1975

Pontosphaera discopora Schiller, 1925

Oolithotus fragilis (Lohmann, 1912) Okada and McIntyre, 1977

Scyphosphaera globulata Bukry and Percival, 1971

Reticulofenestra haqii Backman, 1978

Emiliania huxleyi (Lohmann, 1902) Hay and Mohler, 1967

Discoaster intercalaris Bukry, 1971

Pontosphaera japonica (Takayama, 1967) Nishida, 1971

Pseudoemiliania lacunosa (Kamptner, 1963) Gartner, 1969

Calcidiscus leptoporus (Murray and Blackman, 1898) Loeblich and Tappan, 1978

Discoaster loeblichii Bukry, 1971 
Calcidiscus macintyrei (Bukry and Bramlette, 1969) Loeblich and Tappan, 1978

Sphenaster metula Wilcoxon, 1970

Reticulofenestra minuta Roth, 1970

Reticulofenestra minutula (Gartner, 1967) Haq and Berggren, 1978

Sphenolithus neoabies Bukry and Bramlette, 1969

Helicosphaera neogranulata Gartner, 1977

Gephyrocapsa oceanica Kamptner, 1943

Discoaster pansus (Bukry and Percival, 1971) Bukry, 1973

Coccolithus pelagicus (Wallich, 1877) Schiller, 1930

Discoaster pentaradiatus Tan, 1927

Hayaster perplexus (Bramlette and Riedel, 1954) Bukry, 1973

Amaurolithus primus (Bukry and Percival, 1971) Gartner and Bukry, 1975

Dictyococcities productus (Kamptner, 1963) Backman, 1980

Reticulofenestra pseudoumbilica (Gartner, 1967) Gartner, 1969

Discoaster quinqueramus Gartner, 1969
Geminilithella rotula (Kamptner, 1956) Backman, 1980 Ceratolithus rugosus Bukry and Bramlette, 1968

Thoracosphaera saxea Stradner, 1961

Helicosphaera sellii Bukry and Bramlette, 1969

Umbilicosphaera sibogae (Weber-von Bosse, 1901) Gaarder, 1970

Pontosphaera scutellum Kamptner, 1952

Discoaster stellulus Gartner, 1967

Coccolithus streckeri Takayama and Saito, 1986

Discoaster surculus Martini and Bramlette, 1963

Pontosphaera syracusana Lohmann, 1902

Discoaster tamalis Kamptner, 1967

Ceratolithus telesmus Norris, 1965

Umbellosphaera tenuis (Kamptner, 1937) Paasche, 1955

Amaurolithus tricorniculatus (Gartner, 1967) Gartner and Bukry, 1975

Discoaster triradiatus Tan, 1927

Discoaster tristellifer Bukry, 1976

Discoaster variabilis Martini and Bramlette, 1963 